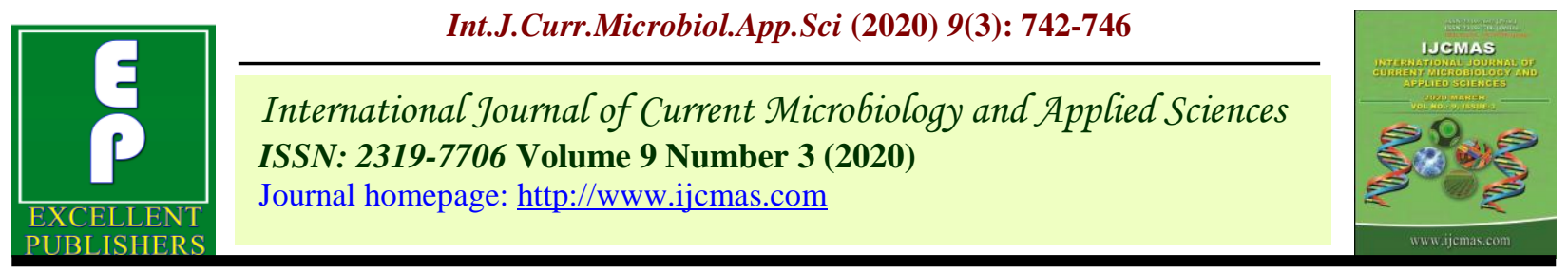

Original Research Article

https://doi.org/10.20546/ijcmas.2020.903.089

\title{
Evaluation of Fennel (Foeniculum vulgare Mill) Genotypes for Seed Yield and its Attributing Traits in Madhya Pradesh, India
}

\author{
Meenakshi Ramgiri ${ }^{1}$ and Reena Nair ${ }^{2 *}$ \\ ${ }^{1}$ AICRP on Vegetable Crops, Department of Horticulture, JNKVV, Jabalpur \\ ${ }^{2}$ Department of Horticulture, JNKVV, Jabalpur, India \\ *Corresponding author
}

\section{A B S T R A C T}

\begin{tabular}{l}
\hline Ke y w or d s \\
$\begin{array}{l}\text { Fennel, } \\
\text { Performance } \\
\text { evaluation, Seed } \\
\text { yield, Madhya } \\
\text { Pradesh }\end{array}$ \\
\hline Article Info \\
\hline $\begin{array}{l}\text { Accepted: } \\
\text { 05 February } 2020 \\
\text { Available Online: } \\
\text { 10 March 2020 }\end{array}$ \\
\hline
\end{tabular}

Evaluation of Fifteen Fennel (Foeniculum vulgare Mill.) genotypes collected from different states for identifying the suitable genotypes for Central India with higher seed yield per plant and other yield and its attributing traits during 2015-16 and 2017-18 recorded significant differences and wide range of variation among the genotypes for all the characters studied. With respect to seed yield q/ha AF-206 (11.55 q/ha) was found to be the highest yielder followed by AF-205 and NDF-67 with 11.53 and $11.34 \mathrm{q} / \mathrm{ha}$ yield. AF-206 was also early flowering and the percent increase over yield of check variety RF-101 and RF-205 is $37.17 \%$ and $17.14 \%$ respectively. The genotype NDF-51, UF-290, UF-291, AF-205, HF-212, HF-212 were found promising in respect of farmers preference.

\section{Introduction}

Fennel (Foeniculum vulgare Mill.), belongs to family Apiaceae and is native of Europe and Mediterranean region its seeds are used as spices. Mature fennel fruits and essential oil are used as flavouring agents in food products such as bread, pickles, pastries, cheese etc. Fennel fruits are used in diseases like cholera, bile disturbances, nervous disorders, constipation, dysentery and diarrhea and also used for control of diseases attacking chest, lungs, spleen, and kidney and in colic pain.
The importance of fennel based on its medicinal value and export potential as spices was recognized long back but it remained neglected for a long time from scientific attention for its improvement in its productivity as well as its quality (Choudhary et al., 2017). The success of any breeding methodology for improving morphological characters depends primarily on the existence of high magnitude of genetic variability and its efficient utilization. Although many improved varieties of fennel have been released in the country but still there is no 
improved variety released from Madhya Pradesh for Central India. Hence, there is still ample scope for crop improvement by traditional and advanced methods of breeding to increase the adaptability and productivity of the crop. The objectives of the present study was to evaluate the performance of thirteen genotypes of fennel with two check RF-101 and RF-205 received from various parts of the country under AICRP on Seed Spices for growth and yield parameters under Kymore Plateau and Satpura Hills Agroclimatic zones of Madhya Pradesh.

\section{Materials and Methods}

Thirteen fennel genotypes along with two checks RF-101 and RF-205 were evaluated in randomized block design (RBD) with three replications during rabi for three consecutive years 2015-2016 to 2017-18 at Department of Horticulture, JNKVV, Jabalpur. Each entry was sown in plots of size $3 \times 2.4 \mathrm{~m}$ at $30 \mathrm{~cm}$ and $10 \mathrm{~cm}$ distance between rows and plants, respectively. Timely management practices were followed to grow a good crop. All the recommended agronomic practices were adopted for raising a good crop.

The data on days to first flowering was recorded on plot basis, while ten randomly selected plants from each of the entry in each replication were tagged for recording the observations on plant height $(\mathrm{cm})$, number of branches per plant, number of umbels/ plant and Seed yield $\mathrm{q} / \mathrm{ha}$. Analysis of variance was carried out as per the procedure suggested by Panse and Sukhatme, 1963.

\section{Results and Discussion}

The pooled mean squares due to genotypes were highly significant for all the characters indicating that the presence of genetic diversity in the material (Table 1) Sengupta et al., (2014) Ghanshyam et al., (2015) and
Mamatha et al., (2017) reported the same findings in thirteen genotypes of fennel evaluated at Vegetable Research Farm, Department of Horticulture, JNKVV, Jabalpur. Scrutiny of results on days to first flowering revealed that genotype JF-576 was earliest which flowered in 92.55 days and was at par with AF-206 (93.22 days ) and national check RF-101 (94.11 days). Plant height varied from $141.407 \mathrm{~cm}$ to $174.153 \mathrm{~cm}$. Genotype NDF-51 $(174.15 \mathrm{~cm})$ was the tallest followed by UF-290 (167.96 cm) and AF-205 $(167.67 \mathrm{~cm})$. These two genotypes are at par with NDF-51. Minimum height was recorded in check variety RF-205 $(141.41 \mathrm{~cm})$. In case of number of branches per plant check variety RF-101 recorded the highest number of branches (8.83) whereas it was minimum (6.81) in JF-576. Fennel genotypes HF-212 and HF-212 were found to be at par with 8.56 and 8.51 branches per plant respectively. Number of umbels per plant was observed to be maximum in check variety RF-101 (22.22) which was at par with UF-291 (18.47) and another check variety RF-205 (18.27). HF212 (13.12) had minimum number of umbels per plant. With respect to seed yield $\mathrm{q} / \mathrm{ha} \mathrm{AF}-$ $206(11.55 \mathrm{q} / \mathrm{ha})$ was found to be the highest yielder followed by AF-205 and NDF-67 with 11.53 and $11.34 \mathrm{q} /$ ha yield. AF-206 was also early flowering. PF-1 was found to be poor yielder with just 5.36q/ha seed yield.

The percent increase in yield of the genotypes over the two national check is depicted in Table-2. The scrutiny of the data shows that the increases in seed yield of AF-206 over the check varieties RF-101 and RF-205 is 37.173 and 17.140 respectively. Likewise, for AF205 it was $36.936 \%$ and $16.937 \%$ increase over RF-101 and RF-205 respectively. Genotype PF-1 was the lowest yielder also as well as reported to have reduced yield than the check varieties by $-36.342 \%$ and -45.639 $\%$. 
Table.1 Performance of Fennel genotypes for growth parameters pooled data of three years (2015-16 to 2017-18)

\begin{tabular}{|l|l|l|l|l|l|l|}
\hline S. No & Varieties & $\begin{array}{l}\text { Days to first } \\
\text { flowering }\end{array}$ & $\begin{array}{l}\text { Plant } \\
\text { height }\end{array}$ & $\begin{array}{l}\text { No. of } \\
\text { branches/p } \\
\text { lant }\end{array}$ & $\begin{array}{l}\text { No. of } \\
\text { umbels/ } \\
\text { plant }\end{array}$ & $\begin{array}{l}\text { Seed yield } \\
\text { (q/ha) }\end{array}$ \\
\hline $\mathbf{1 .}$ & JF-576 & 92.55 & 160.09 & 6.81 & 16.99 & 10.16 \\
\hline $\mathbf{2 .}$ & JF-2012-9 & 95.11 & 159.09 & 7.65 & 14.23 & 8.95 \\
\hline $\mathbf{3 .}$ & UF-290 & 94.44 & 167.96 & 8.01 & 14.87 & 9.72 \\
\hline $\mathbf{4 .}$ & UF-291 & 96.22 & 165.10 & 7.99 & 18.47 & 8.94 \\
\hline $\mathbf{5 .}$ & AF-205 & 96.44 & 167.67 & 8.12 & 14.12 & 11.53 \\
\hline $\mathbf{6 .}$ & AF-206 & 93.22 & 165.17 & 6.84 & 14.71 & 11.55 \\
\hline $\mathbf{7 .}$ & NDF-51 & 98.67 & 174.15 & 7.24 & 15.70 & 10.92 \\
\hline $\mathbf{8 .}$ & NDF-67 & 99.89 & 167.24 & 7.36 & 16.74 & 11.34 \\
\hline $\mathbf{9 .}$ & HF-151 & 95.00 & 164.56 & 7.55 & 17.82 & 7.60 \\
\hline $\mathbf{1 0 .}$ & HF-212 & 96.00 & 159.72 & 8.56 & 13.12 & 7.42 \\
\hline $\mathbf{1 1 .}$ & RF-15 & 99.44 & 160.77 & 8.51 & 17.18 & 9.75 \\
\hline $\mathbf{1 2 .}$ & RF-68 & 92.55 & 162.51 & 6.85 & 16.75 & 7.03 \\
\hline $\mathbf{1 3 .}$ & PF-1 & 99.67 & 159.78 & 7.85 & 16.99 & 5.36 \\
\hline $\mathbf{1 4 .}$ & RF-101 (NC) & 94.11 & 146.84 & 8.83 & 22.22 & 8.42 \\
\hline $\mathbf{1 5 .}$ & RF-205 (NC) & 97.44 & 141.41 & 7.45 & 18.27 & 9.86 \\
\hline & CD 5\% & 4.67 & 13.20 & 1.20 & 4.11 & 2.23 \\
\hline & SEm \pm & 1.60 & 4.53 & 0.41 & 1.41 & 0.77 \\
\hline & SEd & 2.27 & 6.41 & 0.58 & 2.00 & 1.08 \\
\hline & CV \% & 2.89 & 4.86 & 9.26 & 14.78 & 14.38 \\
\hline & & & & & & \\
\hline
\end{tabular}


Table.2 Performance of fennel genotypes for the seed yield (Pooled)

\begin{tabular}{|c|c|c|c|c|}
\hline S. No & Varieties & $\begin{array}{l}\text { Seed yield } \\
\text { (q/ha) }\end{array}$ & $\begin{array}{l}\text { \% increase over } \\
\text { Check RF-101 }\end{array}$ & $\begin{array}{c}\text { \% increase over } \\
\text { Check RF-205 }\end{array}$ \\
\hline 1. & JF-576 & 10.16 & 20.665 & 3.043 \\
\hline 2. & JF-2012-9 & 8.95 & 6.295 & -9.229 \\
\hline 3. & UF-290 & 9.72 & 15.439 & -1.420 \\
\hline 4. & UF-291 & 8.94 & 6.176 & -9.331 \\
\hline 5. & AF-205 & 11.53 & 36.936 & 16.937 \\
\hline 6. & AF-206 & 11.55 & 37.173 & 17.140 \\
\hline 7. & NDF-51 & 10.92 & 29.691 & 10.751 \\
\hline 8. & NDF-67 & 11.34 & 34.679 & 15.010 \\
\hline 9. & HF-151 & 7.60 & -9.739 & -22.921 \\
\hline 10. & HF-212 & 7.42 & -11.876 & -24.746 \\
\hline 11. & RF-15 & 9.75 & 15.796 & -1.116 \\
\hline 12. & RF-68 & 7.03 & -16.508 & -28.702 \\
\hline 13. & PF-1 & 5.36 & -36.342 & -45.639 \\
\hline 14. & RF-101 (NC) & 8.42 & & \\
\hline 15. & RF-205 (NC) & 9.86 & & \\
\hline & CD $5 \%$ & 2.23 & & \\
\hline & SEm \pm & 0.77 & & \\
\hline & SEd & 1.08 & & \\
\hline & CV \% & 14.38 & & \\
\hline
\end{tabular}

Therefore due to the range of variation in the mean values it is substantiated that variability is present in the germplasm and there is a scope for selection of genotypes with desirable component characters for breeding program.

\section{Acknowledgement}

The authors are thankful to PC unit. AICRP on Spices, IISR, Kozikode, Kerala for providing necessary funds for conducting the research work.

\section{References}

Choudhary S, Pereira A, Basu S and Verma AK (2017) Differential antioxidant composition and potential of some commonly used Indian spices. Journal of AgriSearch. 4 (3): 160-166.

Ghanshyam, Dodiya NS, Sharma SP, Jain HK and Dashora A (2015) Assessment of genetic variability, correlation and path analysis for yield and its components in ajwain (Trachyspermum ammi L.) Journal of Spices and Aromatic Crops 
24(1): 43-46.

Mamatha NC, Tehlan SK, Srikanth M, Ravikumar T, Batra VK, Karthik RP and Nalla MK (2017) Mean performance of 150 fenugreek (Trigonella foenum-graecum L.) genotypes for yield and yield contributing traits. International Journal of Pure and Applied Bioscience 5 (3): 1097-1102.

Panse VG and Sukhatme PV (1967) Statistical Methods for Agricultural
Workers. I.C.A.R., New Delhi. $2^{\text {nd }}$ Enlarge Edition 328p

Sengupta SK, Verma BK and Naidu AK (2014) Genetic variability study in fennel (Foeniculum valgare Mill) International Science Journal 1 (1): 2348 - 6058 (Online)

Spice Board (2019) Statistics, Spice Board of India, Ministry of Commerce and Industry, GoI.

\section{How to cite this article:}

Meenakshi Ramgiri and Reena Nair. 2020. Evaluation of Fennel (Foeniculum vulgare Mill) Genotypes for Seed Yield and its Attributing Traits in Madhya Pradesh, India. Int.J.Curr.Microbiol.App.Sci. 9(03): 742-746. doi: https://doi.org/10.20546/ijcmas.2020.903.089 